Home | Archives | About | Login | Submissions | Notify | Contact | Search

ES Home $>$ Vol. 5, No. $1>$ Art. 3

Copyright (c) 2001 by The Resilience Alliance

The following is the established format for referencing this article:

Cane, J. H. 2001. Habitat fragmentation and native bees: a premature verdict? Conservation Ecology 5(1): 3.

[online] URL: http://www.consecol.org/vol5/iss1/art3/

A version of this article in which text, figures, tables, and appendices are separate files may be found by following this link.

Synthesis, part of Special Feature on Pollinator Decline

\title{
Habitat Fragmentation and Native Bees: a Premature Verdict?
}

James H. Cane

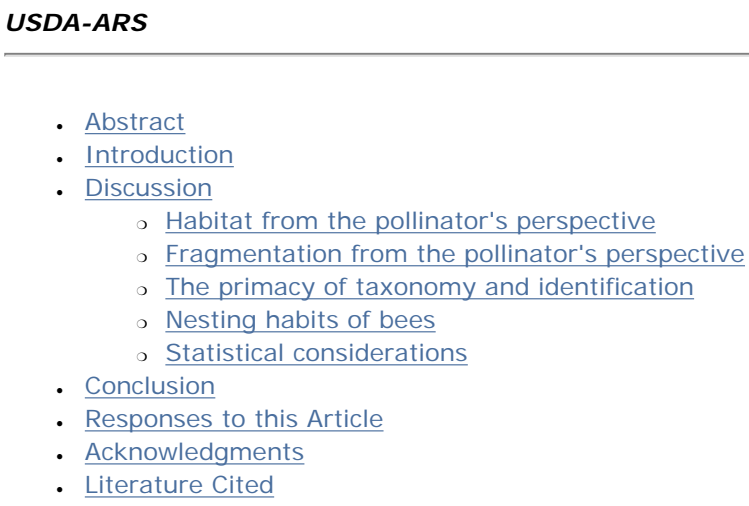

\section{ABSTRACT}

Few studies directly address the consequences of habitat fragmentation for communities of pollinating insects, particularly for the key pollinator group, bees (Hymenoptera: Apiformes). Bees typically live in habitats where nesting substrates and bloom are patchily distributed and spatially dissociated. Bee studies have all defined habitat fragments as remnant patches of floral hosts or forests, overlooking the nesting needs of bees. Several authors conclude that habitat fragmentation is broadly deleterious, but their own data show that some native species proliferate in sampled fragments. Other studies report greater densities and comparable diversities of native bees at flowers in some fragment size classes relative to undisrupted habitats, but find dramatic shifts in species composition.

Insightful studies of habitat fragmentation and bees will consider fragmentation, alteration, and loss of nesting habitats, not just patches of forage plants, as well as the permeability of the surrounding matrix to interpatch movement. Inasmuch as the floral associations and nesting habits of bees are often attributes of species or subgenera, ecological interpretations hinge on authoritative identifications. Study designs must accommodate statistical problems associated with bee community samples, especially non-normal data and frequent zero $\mathrm{km}$ from nest site to forage patch. Overall, evidence for prolonged persistence of substantial diversity and 

and nesting needs of bees, networks of even small reserves may hold hope for sustaining considerable pollinato diversity and the ecological services pollinators provide.

KEY WORDS: Apoidea, bees, conservation, diversity, habitat fragmentation, land-use change, pollination, pollinator, statistics, taxonomy.

\section{NTRODUCTI ON}

A number of conservation-minded reviews have concluded that habitat fragmentation is broadly deleterious to invertebrate pollinators (Rathcke and Jules 1993, Buchmann and Nabhan 1996, Matheson et al. 1996, Murcia 1996, Renner 1996). In point of fact, the number of reviews that draw this conclusion nearly outnumber the published studies on which the conclusion might be based. Partly because of their relative ease of identification, butterflies are the primary floral visitors considered in studies of habitat fragmentation (Baz and Garcia-Boyero 1995; T. H. Ricketts, unpublished manuscript). However, they do not seem to be important pollinators except in the tropics. Outside of equatorial regions, bees-and, in alpine habitats, flies too (Kearns 2001) - are without a doubt the principal group of invertebrates that pollinate. Bees, especially social species, are key pollinators of the continental lowland tropics as well, especially in forested regions. Despite the prevalence of bees, their taxonomic and ecological diversity has too often been underappreciated or misunderstood in the few studies that have attempted to evaluate their responses to habitat fragmentation.

Different animal groups respond differently to the same disturbance regime, as has been shown for select biodiversity indicator taxa in several conservation studies (e.g., Lawton et al. 1998). Hence, mistaken notions can arise when broad ecological generalizations about one well-known animal group are applied to others. To understand the ways in which bees respond to ecological change, it is necessary to study bees. In this review, focus on habitat fragmentation and bees, not pollination, which is addressed elsewhere in this issue (Thomson 2001). The salient pollination literature frequently involves pollinator taxa other than bees (e.g., bats, hummingbirds, butterflies) or else does not deal with pollinators at all.

\section{DISCUSSION}

\section{Habitat from the pollinator's perspective}

What is "habitat" to an invertebrate pollinator when it comes to the fragmentation of habitats? For butterflies and moths, the minimum requirements for habitat must include larval food plants as well as adult food resources; the latter is typically nectar, but may also include dung, tree sap, and rotting fruit. For some taxa, such as lycaenid butterflies, habitat will also include the presence of mutualists such as ants (Thomas 1996). Larval hosts and habitats must also be considered for other invertebrate floral visitors, such as flies and beetles, when assessing the effects of habitat fragmentation. A natural spatial mosaic of such nonsubstitutable essential resources, conceptually termed "landscape complementation" (Dunning et al. 1992), forces many organisms, such as birds, bats, and bees, to travel frequently between forage patches and their nests or roosts through a permeable but unrewarding habitat matrix.

Habitat for any species of bee must minimally consist of rewarding patches of floral resources plus suitable nesting sites, all within flight range of each other. The suitability of floral resources varies with species. All bee species have broadly catholic tastes for nectar, but many nonsocial species have fixed species-specific predilections or even requirements for pollen from a few particular related genera of floral hosts; this phenomenon, known as "oligolecty," was most recently reviewed by Wcislo and Cane (1996). For these species, adult emergence must coincide with host bloom on a seasonal and annual basis, or the species must be able to switch floral hosts. Multivoltine or long-lived bee species (or their colonies) have a different problem: their foraging seasons typically outlast the blooming period of any one host. Consequently, within the radius of flight range from their nest sites, there must exist patches of various floral species that bloom at different times of the year.

Suitable nesting substrates for bees vary with species, and may include holes of appropriate diameter left by wood-boring beetles, tree cavities, pithy or hollow plant stems of the correct diameter, abandoned rodent burrows, or soils of suitable texture, depth, slope, vegetation cover, and moisture. Additional resources needed by 
some bee species for nesting include nearby mud, resins, pebbles, or plant hairs, which they use to line, partition, and plug their nests (O'Toole and Raw 1991). Mud foraging and transport alone can occupy a significant portion of a bee's daily foraging effort (Rust 1993). The importance of nearby suitable nesting habitat for the presence of specific bee species is underscored by the relative paucity of cavity-nesting bees in flowering agricultural fields, such as seed alfalfa or lucerne (Medicago sativa), that otherwise provide a wealch of floral resources (Gathmann et al. 1994). Although poorly understood for bees, the permeability of the matrix surrounding habitat patches for flying pollinators is probably as important as the linear distances between patches in defining patch isolation, as has been shown for alpine butterlies (T. H. Ricketts, unpublished manuscript). Communities of bees contain species that differ in these natural history attributes, which consequently affect their responses to habitat patchiness and fragmentation.

\section{Fragmentation from the pollinator's perspective}

What is "fragmentation" from the perspective of an invertebrate pollinator? Fragmentation describes a patchy distribution of suitable habitats, sometimes thought of as "ecological islands," surrounded by a matrix of inhospitable or inadequate habitats of varying permeability (T. H. Ricketts, unpublished manuscript). Fragmentation means more than the mere existence of isolated or patchy habitats; it also implies that a more continuous habitat has been subdivided or broken up by some (often anthropogenic) process, with the attendan loss of intervening habitat. The distributions and population dynamics of bee species in naturally patchy habitats (e.g., bumble bees in alpine meadows) can yield insights into some, but not all, of the factors associated with habitat fragmentation (Bowers 1985). Naturally patchy distributions are the norm for wildflowers, shrubs, and trees.

For bees, suitable nesting substrates are invariably patchy as well at some spatial scale, and often separate from their floral hosts. Spatially dissociated nest sites and forage patches necessitate from several to dozens of commutes per day between a mother bee's nesting site and her foraging site. Impressive commute distances are readily achieved by bees as large as honey bees (Fabré 1914, Rau 1929, Roubik and Aluja 1983); a haphazard review of home range radii and/or commute distances for 10 such species (eight published accounts, two unpublished) yields an average home-range radius of $2.8 \mathrm{~km}$ with a median of $1.5 \mathrm{~km}(\mathrm{~J}$. H. Cane, unpublished unpublished)

The ultimate effects of habitat fragmentation may be confounded by the extensive disturbance or transient population dynamics (Hagan et al. 1996) that accompany the fragmentation event itself, assuming that research sampling follows on the heels of the disruption. Furthermore, short-term shifts may not foreshadow long-term changes (Debinski and Holt 2000, Roubik 2001). At the Biological Dynamics of Forest Fragments Project north of Manaus, Brazil, replicate forest fragments 1,10 , and 100 ha in size were carved from continuous lowland rain forest through massive clear-cutting in 1982 and 1983. Those very same years, within weeks or months of the logging, Powell and Powell (1987) resampled male orchid bees using scented baits (see Table 1). They reported dramatic declines in the abundances of the three most common species of Euglossa, namely Euglossa chalybeata ( emerged for species of Eulaema and two less common genera of orchid bees.

Table 1. Attributes of habitat fragmentation studies for native bee communities.

\begin{tabular}{|c|c|c|c|c|c|c|c|c|c|c|}
\hline Country & Habitat & $\begin{array}{c}\text { Cause of } \\
\text { fragmentation }\end{array}$ & $\begin{array}{l}\text { No. } \\
\text { frag. }\end{array}$ & $\begin{array}{c}\text { Range } \\
\text { fragment } \\
\text { sizes }\end{array}$ & $\begin{array}{l}\text { Range } \\
\text { frag. } \\
\text { ages }\end{array}$ & $\begin{array}{l}\text { No. } \\
\text { bee } \\
\text { taxa }\end{array}$ & $\begin{array}{l}\text { No. non- } \\
\text { Apis bees }\end{array}$ & Reference & $\begin{array}{c}\text { Author's interpretation (from } \\
\text { abstract) }\end{array}$ & Limitations of interpretation \\
\hline Brazil & $\begin{array}{l}\text { Rain } \\
\text { forest }\end{array}$ & $\begin{array}{l}\text { Experimental } \\
\text { deforestation }\end{array}$ & 4 & $1-100$ ha & $<1 \mathrm{yr}$ & 16 & 1092 & $\begin{array}{l}\text { Powell and } \\
\text { Powell } \\
\text { (1987) }\end{array}$ & $\begin{array}{l}\text { "For most [euglossine] bee } \\
\text { species, visitation rate declined } \\
\text { with fragment size ..." }\end{array}$ & $\begin{array}{l}\text { Deforestation same season as sampling, } \\
\text { disturbance or fragmentation effects? Bees at } \\
\text { bait stations identified live, not collected, so two } \\
\text { most common species confounded } \neq\end{array}$ \\
\hline Brazil & $\begin{array}{l}\text { Rain } \\
\text { forest }\end{array}$ & $\begin{array}{l}\text { Experimental } \\
\text { deforestation }\end{array}$ & 7 & $1-100$ ha & $5-8 \mathrm{yr}$ & 16 & 290 & $\begin{array}{l}\text { Becker et al. } \\
\text { (1991) }\end{array}$ & $\begin{array}{l}\text { "[Orchid bee] species richness } \\
\text { unaffected by forest } \\
\text { fragmentation ..." and "... bee } \\
\text { abundance greater in } 10 \text { and } \\
100 \text { ha fragments than in } \\
\text { continuous forest." }\end{array}$ & $\begin{array}{l}\text { Inefficient passive trapping method } \neq \text { and small } \\
\text { number of fragments } \neq\end{array}$ \\
\hline
\end{tabular}




\begin{tabular}{|c|c|c|c|c|c|c|c|c|c|c|}
\hline Argentina & $\begin{array}{l}\text { Dry } \\
\text { thorn } \\
\text { scrub }\end{array}$ & $\begin{array}{l}\text { Agricultural } \\
\text { clearing }\end{array}$ & 8 & $0.5-21$ ha & $5-20 y r$ & $\begin{array}{c}43 \\
(24 *)\end{array}$ & 481 & $\begin{array}{l}\text { Aizen and } \\
\text { Feinsinger } \\
\text { (1994) }\end{array}$ & $\begin{array}{l}\text { "Frequency and taxon richness } \\
\text { of native floral visitors...declined } \\
\text { with decreasing forest-fragment } \\
\text { size." }\end{array}$ & $\begin{array}{l}\text { Limited taxonomic resolution,* small number of } \\
\text { fragments, } \neq \text { application of ANOVA to data set } \\
\text { with } 84 \% \text { of values at zero }\end{array}$ \\
\hline Germany & Grassland & $\begin{array}{l}\text { Agricultural } \\
\text { clearing }\end{array}$ & $40 \dagger$ & 4 pots & $\begin{array}{c}\text { ca. 1 } \\
\text { montht }\end{array}$ & 23 & 212 & $\begin{array}{l}\text { Stefan- } \\
\text { Dewinter and } \\
\text { Tscharntke } \\
\text { (1999) }\end{array}$ & $\begin{array}{l}\text { "Habitat connectivity essential } \\
\text { to maintain ... abundant and } \\
\text { diverse bee communities." }\end{array}$ & $\begin{array}{l}\text { Do eight potted plants constitute a "habitat } \\
\text { island?" No relation between spatial isolation and } \\
\text { bee body size, bee nesting needs not considered, } \\
\text { bee species not listed }\end{array}$ \\
\hline USA & $\begin{array}{l}\text { Scrub } \\
\text { desert }\end{array}$ & Urbanization & 59 & $20 \mathrm{~m}^{2}-2 \mathrm{ha}$ & $5-70 y r$ & 59 & 2512 & $\begin{array}{l}\text { Cane et al., } \\
\text { unpublished } \\
\text { manuscript }\end{array}$ & $\begin{array}{l}\text { "... greater densities of native } \\
\text { bees ... in the smaller } \\
\text { fragments" and "Fragmentation } \\
\text { [only] dramatically affected } \\
\text { ground-nesting [floral] } \\
\text { specialists." }\end{array}$ & $\begin{array}{l}\text { Nesting/foraging value of urban matrix not } \\
\text { measured, } \neq \text { pollination consequences not } \\
\text { measured, } \neq \text { weak documentation of spatial } \\
\text { relations of fragments } \neq\end{array}$ \\
\hline
\end{tabular}

* Nineteen bee taxa identified only to family; only three identified to species level ( $9 \%$ of individuals).

† In agricultural fields adjacent to eight grassland remnants, authors placed 40 "habitat islands" (which

they refer to as "fragments") consisting of four pots, each with one radish and one mustard plant.

$\neq$ Problem recognized by authors.

Six years later, Becker et al. (1991) again resampled orchid bees at the same study site (Table 1). E. chalybeata and $\mathrm{E}$. stibonata had recovered in abundance, accounting for $85 \%$ of the orchid bees sampled. E. crassipuncta was missed because the only scent that had attracted it in 1982-1983, vanillin, had been replaced by skatole. The latter study reported that, six years after the deforestation event, more individuals of the two most commo orchid bee species were sampled in both the 10-ha and the 100-ha forest fragments than in the continuous forest control itself. Becker et al. (1991) suggested that the immediate disturbance caused by massive clear-
cutting, and not fragmentation per se, was responsible for the findings of Euglossa declines in smaller fragments (Powell and Powell 1987). Additionally, Becker et al. (1991) noted that the matrix of secondary growth in the clearcuts "provides diverse nest sites and is rich in resin sources [used for nesting]." The immediate effects of dramatic landscape disturbances, such as logging, fire, and volcanism, may overshadow more subtle effects of fragmentation for pollinators.

Studies based on the experimental fragmentation or isolation of "habitats" must consider more than just the presence of flowering plants before drawing conclusions about the resultant effects on communities of invertebrate pollinators. Further, bloom must be available at the time of year when the given pollinator species flies. As an extreme example, data on insect visitation to tiny arrays of potted flowering plants set out in agricultural fields have been used to draw conclusions about the "effects of habitat isolation on pollinato communities" (Steffan-Dewenter and Tscharntke 1999), but, in reality, the isolated elements in such studies are the potted plants, not the habitats in which the bee community lives (Table 1 . Plants of this type are studies are the potted plants, entirely analogous to arrays of bird feeders. Such studies are appealing, because they allow for controlled experimental manipulation and can be performed in a single field season, yielding insights into the reproductive shortfalls and conservation needs of founder or remnant plant populations. However, because these experiments do not alter pollinator habitats, it is impossible to draw conclusions about the responses of pollinator communities from experimental manipulations that do nothing more than deploy small arrays of flowering hosts.

\section{The primacy of taxonomy and identification}

Authoritative identification of bees at the species level is in many ways crucial for researchers who seek to ascribe particular nesting habits, phenologies, degrees of sociality, and floral associations to a sampled bee. For example, North America and Central America are home to $>25$ species of the bee genus Diadasia, nearly all of which are floral specialists. However, each species is associated with one of five different unrelated plant families and, in some cases, specific genera therein (Linsley and MacSwain 1958). Likewise, widespread genera of predominately cavity-nesting species (e.g., Megachile, Osmia) contain a number of ground-nesting species whose nesting habits cannot be determined from any visible attributes of a pinned specimen (Eickwort et al. 1981). Clearly, the reliable assignment of a species epithet or at least a generic name to specimens sampled from a bee fauna is critical to defining the ecological attributes that mediate their responses to habitat fragmentation.

These taxonomic concerns are applicable to extant studies of bees and habitat fragmentation. For instance, Aizen and Feinsinger (1994 a, b) dealt with the poorly known bee fauna inhabiting the subtropical dry forests of northern Argentina. Surprisingly, no bee taxonomists were listed in their acknowledgments despite the taxonomic difficulty of the fauna. Perhaps as a consequence, only three of 43 bee taxa caught in their pan traps 
were identified with regard to species, and nearly half were resolved only at the familial level (Aizen and Feinsinger 1994b: Appendix II), although statistically they were treated as separate and specific entities. Even though that study's intended focus was the pollinator guild of two leguminous shrubs, a number of the pantrapped individuals appeared to be cactus specialists (e.g., Arhysosage). Much biologically meaningful detracts from their ecological interpretations.

The pair of Brazilian orchid bee studies differs in terms of taxonomic care, which likewise confounds interpretation. Both used scented lures to attract males. The earlier study identified individuals on the wing (Powell and Powell 1987), whereas the later study caught all visiting bees in McPhail traps (Becker et al. 1991) In both of the common genera, Powell and Powell found that field counts of bees had confused several similarlooking species, leading Becker et al. (1991) to conclude that "capture is necessary for censusing euglossines if accurate species determinations are desired." In general, field identifications should be undertaken only for unambiguously distinguishable species present in a well-known fauna, and even then a subsample of pinned voucher specimens is a necessity for future comparisons, as reported by Marlin and LaBerge (2001). Just as is true for birds, mammals, and plants, taxonomy is key to the proper interpretation of the responses of bee species to anthropogenic changes, including habitat fragmentation.

To somewhat alleviate the difficulties of bee taxonomy, which can be daunting, researchers should consider manually sampling floral guilds whenever possible (i.e., netting bees at a single flowering species) rather than passively sampling entire bee communities (e.g., via pan traps, flight intercept traps, Malaise traps). Passive sampling techniques are proving to have their own taxonomic biases. Pan traps, for instance, preferentially catch small-bodied bees, especially sweat bees, and miss many bee taxa altogether ( $\mathrm{J}$. H. Cane, unpublished manuscript; T. L. Griswold, unpublished manuscript). Manual sampling is more time-consuming and tedious, requiring field personnel with some training, but thereafter collections of manually sampled floral guilds provide benefits for the researcher that cannot be obtained for passively sampled pollinator communities. First, reliable data for floral associations can greatly aid bee identifications, especially where oligoleges are concerned, as in the Diadasia case mentioned above or for European Melitta (Westrich 1989). The two largest bee genera in North America, Perdita and Andrena, are laden with floral specialists.

Moreover, samples from guilds typically contain fewer instances of difficult congenerics that need to be distinguished, as well as more cases in which a genus is represented by a single species in a given guild. With guild samples, the researcher is more apt to be keying specimens to genus, not species, to gain a specific epithet. In a subcontinental survey of the bee fauna associated with the common desert shrub Larrea tridentata, $89 \%$ of the 4803 sampled individuals belonged to 19 species representing 12 different genera (Minckley et al. 1999). With training and access to a reasonable voucher collection, researchers can now distinguish bee genera not only in North and Central America (Michener et al. 1994), but across much of the world (Michener 2000). Finally, it is reasonable to expect that ecologists and conservation biologists will need to formally enlist the services of a museum taxonomist in their research programs. Both the ecologist and the taxonomist can benefit from collaboration, and their joint research will contain insights that neither would gain alone.

\section{Nesting habits of bees}

Bees and the pollen wasps are the sole central-place foragers among common invertebrate pollinators. Many, if not most, bee species nest underground; others nest aboveground, often in pre-existing tunnels in deadwood or in dead stems whose soft pith they have excavated. A very few species make free-standing nests. Within these broad categories, there may be further specialization, especially among ground nesters, who sometimes have specific requirements with regard to soil texture, moisture, salinity, and aspect (Cane 1991). The bee Hesperapis oraria provides an instructive example. Its geographic range and local occurrence are entirely bounded by the presence of the friable sands of the vegetated backdunes found along the northern margins of the Gulf of Mexico. Even in areas where its sole floral host extends inland beyond the reach of these dunes, the bee is absent (Cane et al. 1996). Clearly, the loss, alteration, or fragmentation of such specific required nesting substrates should have profound consequences for the local extinction, persistence, or even proliferation of individual bee species. Nevertheless, all pollinator habitat fragmentation studies to date that involve bees define fragments as recognizable parcels or patches of flowering vegetation.

Tantalizing insights can be found in habitat fragmentation studies with regard to the prominent role played by the nesting attributes of bees. In the Argentinian study of subtropical dry forest fragmentation, only two bee taxa, Dialictus and Augochlora, were detected in all three continuous forest samples (Aizen and Feinsinger 1994b). Although both these genera consist largely of floral generalists, Dialictus, which are all ground nesters, were present in samples from all forest fragments and in the "agricultural matrix" as well, whereas Augochlora, two subgenera of which nest in rotting tree stumps and logs, fared poorly in small fragments and farmers' fields. Could the contrasting response to deforestation by the bees in these two genera reflect the fact that the small fragments and the agricultural matrix still contain soils that are suitable for Dialictus, but no longer contain the stumps and rotten logs that are the preferred nesting sites of Augochlora? The contrasting responses of these biologies, not their floral biologies, although such an assertion must be based on knowledge of the identities, 

own evidence to the contrary, the authors nevertheless concluded that "fragmentation ... appears to affect native flower-visitors adversely" in the case of these aboveground nesters.

Likewise, a study of urban habitat fragmentation and native desert bees (J. H. Cane et al., unpublished manuscript) found that a number of cavity-nesting bee species of Xylocopa and the Megachilidae, including a Larrea specialist, were actually more ubiquitous and abundant at flowers of Larrea tridentata growing well within the city of Tucson, Arizona, than at flowers in outlying desert, perhaps because the older residential
neighborhoods that they sampled offered more woody nesting substrates than did the scrub desert. Unfortunately, the study design failed to anticipate shifts in the availability of nesting substrates. Finally, for the pair of Brazilian orchid bee studies, Becker et al. (1991) concluded that the sampled abundances of orchid bees in the 10- to 100-ha fragments may have eclipsed that of continuous forest because the surrounding matrix of secondary growth offered more nesting sites and more plants that produce the resins that bees use for nesting.

In all of these cases, changes in the habitat matrix that surrounds the fragments appear to have affected the opportunities for nesting by native bees, an outcome that was not anticipated by the researchers and is therefore now relegated to the realm of speculative interpretation. Polylectic bees, in particular, should be able to accommodate the substitutions in floral hosts that sometimes result from fragmentation, but accompanyin alterations of nesting substrates may be key to predicting bee demise or proliferation in the face of habitat alteration.

\section{Statistical considerations}

There is a lack of universal and satisfying strategies for meaningful, insightful, and flexible statistical analyses of the guild and community data that arise in habitat fragmentation studies. Parametric statistics, such as analyses of variance, allow for the greatest flexibility and power, including the evaluation of simultaneous multiple factors and their interactions, different plot designs, missing data, and more. Unfortunately, the collected samples obtained in habitat fragmentation studies often violate the basic assumptions of data normality and independence of means and variances. For instance, Aizen and Feinsinger (1994b: Table 5) applied a three-way ANOVA to a data set (Aizen and Feinsinger 1994b: Appendix II) for which $84 \%$ of their data values were zeros (indicating that a particular species was not represented in a given sample). No transformation could normalize such data for the appropriate application of parametric statistics. If these authors had not persevered in publishing their raw data in an appendix (journals are increasingly loathe to publish appendices of raw data), then their questionable statistical application would not have been apparent. Clearly, diagnostic statistics must accompany such analyses, showing that the assumptions for statistical applications are met. Are there other solutions?

First, thoughtful, precise, and refutable null hypotheses are essential. Second, it might be useful to separate the issues of species incidence and species abundance in faunal samples. This approach is somewhat artificial, because reported absence indicates only a failure to collect the species, which may not have been truly absent but simply overlooked or rare (Marlin and LaBerge 2001). Nevertheless, such an approach can be biologically meaningful, because the causes of local extinction may differ from the factors that influence rarity and abundance. The statistical advantage of this type of analytical strategy is that categorical presence/absence data are often readily handled by familiar contingency tests or logistic regression. Once absence data, i.e., the zeros, are removed from further consideration, the remaining count/density data for species that are present in samples can be more appropriately analyzed by familiar and powerful parametric methods after transformation of the count data, or else by logistic regression, especially if the data can be assigned to an ordered series of bins or class values (J. H. Cane et al., unpublished manuscript).

There are several other statistical strategies whose utility should be considered for the analysis of habitat fragmentation data. One uses models based on maximum likelihood estimates (T. H. Ricketts, unpublished manuscript); another is randomization (i.e., permutation or computer-intensive) statistics. Both of these methods allow for the more creative and potentially more precise definition of null hypotheses accompanied by very relaxed data assumptions and the accommodation of small samples (Noreen 1989). However, because the algorithms for both analytical strategies are freshly derived for a given scenario, they must be carefully designed and precisely presented to allow for scrutiny and testing by colleagues. Well-crafted null hypotheses, appropriate sampling designs, and insights from preliminary data will largely define the statistical strategy that is ultimately adopted in studies of bee guilds or communities and their responses to perturbations such as habitat fragmentation 


\section{CONCLUSION}

Habitat loss at some extreme spatial scale of patch size and isolation is, of course, deleterious to both communities of invertebrate pollinators and the sexual reproduction of plants. Minimally, there must be sufficient acceptable bloom within the flight range of females' nests to support viable nesting populations. At more modest acceptable bloom which most local habitat may no ' spatial scales for which most local habitat may nonetheless be lost or transformed, the composition of native invertebrate communities or loral guilds is often altered, but, in all the cases thus far reported, some native bee species had increased as well as decreased in either abundance or incidence as a consequence of suspected but as yet unproven factors, such as nesting substrate or floral specialization. Useful future studies of habitat fragmentation and invertebrate pollinators, especially bees, must have temporal depth (Roubik 2001), achieve reliable species identifications, incorporate an appreciation of nesting needs as well as floral resources into their design and interpretation, and apply appropriate statistical analyses. Despite our cherished beliefs and spatial models, the importance of fragmentation per se may be eclipsed by habitat loss as a factor explaining the erosion of invertebrate pollinator diversity (Fahrig 1997).

By viewing fragments as reserves, such studies turn our notion of habitat fragmentation on its head and may generate data and practical insights of critical importance for pollinator conservation. In many regions of the world the opportunities to set aside massive reserves are limited, impractical, or already past, requiring us to either think small or else give up hope (Shafer 1995, Abensperg-Traun and Smith 1999). There is growing evidence that substantial fractions of native bee communities can persist in habitats that have been modestly, evidence that substantialliction, 2001). What is the minimal floral carrying capacity for such bee communities, and how resilient are they in the face of annually fluctuating floral resources (Roubik 2001)? What is the rate and degree, if any, of genetic impoverishment in such isolated populations when immigration and genetic drift cease (Packer and Owen 2001)? Can recolonization potential be derived from spatial distributions of nesting habitats, using body size as a surrogate scale for flight range? Can dispersal distance be derived from the foraging ranges of bees? Such management, and spatial distribution of reserves that could support largely intact communities of invertebrate pollinators into the foreseeable future. We are only beginning to understand the possible effects of habitat fragmentation on bees.

\section{RESPONSES TO THIS ARTI CLE}

Responses to this article are invited. If accepted for publication, your response will be hyperlinked to the article. To submit a comment, follow this link. To read comments already accepted, follow this link.

\section{Acknowledgments:}

The perspective of this review benefitted from discussions with participants at an NCEAS workshop charged with evaluating claims for declines in North American invertebrate pollinators. Valuable manuscript reviews were also provided by Claire Kremen, Lenore Fahrig, and two anonymous reviewers. Funded by NSF grant IBN-9896150 and the National Center for Ecological Assessment and Synthesis (NCEAS).

\section{LITERATURE CITED}

Abensperg-Traun, M., and G. T. Smith. 1999. How small is too small for small animals? Four terrestrial arthropod species in different-sized remnant woodlands in agricultural Western Australia. Biodiversity and Conservation 8: 709-726.

Aizen, M. A., and P. Feinsinger. 1994a. Forest fragmentation, pollination, and plant reproduction in a Chaco dry forest. Ecology 75: 330-351.

Aizen, M. A., and P. Feinsinger. 1994b. Habitat fragmentation, native insect pollinators, and feral honey bees in Argentine "Chaco Serrano." Ecological Applications 4: 378-392. 
Baz, A., and A. Garcia-Boyero. 1995. The effects of forest fragmentation on butterfly communities in central Spain. J ournal of Biogeography 22: 129-140.

Becker, P., J. S. Moure, and F. J. A. Peralta. 1991. More about euglossine bees in Amazonian forest fragments. Biotropica 23: 586-591.

Bowers, M. A. 1985. Bumble bee (Bombus) colonization, extinction and reproduction in subalpine meadows in northeastern Utah, USA. Ecology 66: 914-927.

Buchmann, S. L., and G. P. Nabhan. 1996. The forgotten pollinators. Island Press, Washington, D.C., USA.

Cane, J. H. 1991. Soils of ground-nesting bees (Hymenoptera: Apoidea): texture, moisture, cell depth and climate. Journal of the Kansas Entomological Society 64: 406-413.

Cane, J. H., R. R. Snelling, L. J. Kervin, and G. C. Eickwort. 1996. A new monolectic coastal bee, Hesperapis oraria Snelling and Stage (Hymenoptera: Melittidae), with a review of desert and neotropical disjunctives in the southeastern U.S. J ournal of the Kansas Entomological Society 69: 238-247.

Debinski, D. M., and R. D. Holt. 2000. A survey and overview of habitat fragmentation experiments. Conservation Biology 14: 342-355.

Dressler, R. L. 1982. Biology of the orchid bees (Euglossini). Annual Review of Ecology and Systematics 13 373-394.

Dunning, J. B., B. J. Danielson, and H. R. Pulliam. 1992. Ecological processes that affect populations in complex landscapes. Oikos 65: 169-175.

Eickwort, G. C., R. W. Matthews, and J. Carpenter. 1981. Observations on the nesting behavior of Megachile rubi and $M$. texana with a discussion of the significance of soil nesting in the evolution of megachilid bees (Hymneoptera: Megachilidae). J ournal of the Kansas Entomological Society 54: 557-570.

Fabré, J. H. 1914. The Mason-bees. Dodd, Mead, New York, New York, USA.

Fahrig, L. 1997. Relative effects of habitat loss and fragmentation in species extinction. Journal of Wildlife Management 61: 603-610.

Gathmann, A., H. J. Greiler, and T. Tscharntke. 1994. Trap-nesting bees and wasps colonizing set-aside fields -succession and body size, management by cutting and sowing. Oecologia 98: 8-14.

Hagan, J. M., W. M. vander Haegen, and P. S. McKinley. 1996. The early development of forest fragmentation effects on birds. Conservation Biology 10: 188-202.

Jörgensen, P. 1909. Beobachtungen über Blumenbesuch, Biologie, Verbreitung usw. der Bienen von Mendoza (Hym.). Deutsches Entomologische Zeitschrift 46: 211-227.

Kearns, C. A. 2001. North American Dipteran pollinators: assessing their value and conservation status. Conservation Ecology 5(1): ZZ [online] URL: http://www.consecol.org/vol5/iss1/art5.

Lawton, J. H., D. E. Bignell, B. Bolton, G. F. Bloemers, P. Eggleton, P. M. Hammond, M. Hodda, R. D.

Holt, T. B. Larsen, N. A. Mawdsley, and N. E. Stork. 1998. Biodiversity inventories, indicator taxa and effects of habitat modification in tropical forest. Nature (London) 391: 72-76.

Linsley, E. G., and J. W. MacSwain. 1958. The significance of floral constancy among bees of the genus Diadasia (Hymenoptera: Anthophoridae). Evolution 12: 219-223.

Marlin, J. C., and W. E. LaBerge. 2001. The native bee fauna of Carlinville, III., revisted after 75 years: a case for persistence. Conservation Ecology 5(1): ZZ [online] URL: http://www. consecol.org/vol5/iss 1/art9.

Matheson, A., S. L. Buchmann, C. O'Toole, P. Westrich, and I. H. Williams, editors. 1996. The conservation of bees. Academic Press, London, UK.

Michener, C. D. 2000. The bees of the world. Johns Hopkins University Press, Baltimore, Maryland, USA 
Michener, C. D., R. J. McGinley, and B. N. Danforth. 1994. The bee genera of North and Central America (Hymenoptera: Apoidea). Smithsonian Institution Press, Washington, D.C., USA.

Minckley, R. L., J. H. Cane, L. Kervin, and T. H. Roulston. 1999. Spatial predictability and resource specialization of bees (Hymenoptera: Apoidea) at a superabundant, widespread resource. Biological J ournal of the Linnean Society, London 67: 119-147.

Murcia, C. 1996. Forest fragmentation and the pollination of neotropical plants. Pages 19-36 in J. Schelhas and R. Greenberg, editors. Forest patches in tropical landscapes. Island Press, Washington, D.C., USA.

Noreen, E. W. 1989. Computer intensive methods for testing hypotheses. John Wiley, New York, New York, USA.

O'Toole, C., and A. Raw. 1991. Bees of the world. Facts on File, New York, New York, USA.

Packer, L., and R. Owen. 2001. Population genetic aspects of pollinator decline. Conservation Ecology 5(1): ZZ [online] URL: http://www.consecol.org/vol5/iss1/art4.

Powell, A. H., and G. V. N. Powell. 1987. Population dynamics of male euglossine bees in Amazonian forest fragments. Biotropica 19: 176-179.

Rathcke, B. J., and E. S. J ules. 1993. Habitat fragmentation and plant pollinator interactions. Current Science (Bangalore) 65: 273-277.

Rau, P. 1929. Experimental studies in the homing of carpenter and mining bees. Journal of Comparative Psychology 9: 35-70.

Reed, C. C. 1995. Species richness of insects on prairie flowers in southeastern Minnesota. Pages 103-115 in D. C. Hartnett, editor. Proceedings of the 14th Annual North American Prairie Conference. Kansas State University Press, Manhattan, Kansas, USA.

Renner, S. S. 1996. Effects of habitat fragmentation on plant pollinator interactions in the tropics. Pages 339361 in D. M. Newbery, H. T. Prins, and N. D. Brown, editors. Dynamics of Tropical Communities. Blackwell Scientific, Cambridge, UK.

Roubik, D. W. 2001. Ups and downs in pollinator populations: when is there a decline? Conservation Ecology $\mathbf{5}$ (1): ZZ [online] URL: http://www. consecol.org/vol5/iss1/art2.

Roubik, D. W., and M. Aluja. 1983. Flight ranges of Melipona and Trigona in tropical forest. J ournal of the Kansas Entomological Society 56: 217-222.

Rust, R. W. 1993. Cell and nest construction costs in two cavity-nesting bees (Osmia lignaria propinqua and Osmia ribifloris biedermannii) (Hymenoptera, Megachilidae). Annals of the Entomological Society of America $\mathbf{8 6}$ 327-332.

Shafer, C. L. 1995. Values and shortcomings of small reserves. Bioscience (American Institute of Biological Science) 45: 80-88.

Steffan-Dewenter, I., and T. Tscharntke. 1999. Effects of habitat isolation on pollinator communities and seed set. Oecologia 121: 432-440.

Thomas, J. A. 1996. The case for a science-based strategy for conserving threatened butterfly populations in the UK and north Europe. Pages 1-6 in J. Settele, C. R. Margules, P. Poschlod, and K. Henle, editors. Species survival in fragmented landscapes. Kluwer Academic, Amsterdam, the Netherlands.

Thomson, J. D. 2001. Using pollination deficits to infer pollinator declines: can theory guide us? Conservation Ecology 5(1): ZZ [online] URL: http://www.consecol. org/vol5/iss1/art6.

Wcislo, W. T., and J. H. Cane. 1996. Floral resource utilization by solitary bees (Hymenoptera: Apoidea) and exploitation of their stored foods by natural enemies. Annual Review of Entomology 41: 195-224. 
Westrich, P. 1989. Die Wildbienen Baden-Württembergs. Allgemeiner Teil: Lebensräume, Verhalten, Ökologie und Schutz. Verlag Eugen Ulmer, Stuttgart, Germany.

Williams, N., R. Minckley, and F. Silviera. 2001. Variation in native bee faunas and its implications for detecting community changes. Conservation Ecology 5(1): ZZ [online] URL: http://www. consecol.org/vol5/iss1/ art7.

Address of Correspondent:

James H. Cane

USDA Bee Biology Lab and

Department of Biology

Utah State University

Logan, Utah, USA 84322-5310

Phone: (435) 797-3879

Fax: (435) 797-0461

jcane@biology.usu.edu

Home | Archives | About | Login | Submissions | Notify | Contact | Search 